\title{
PENGARUH PERSEPSI SISWA TENTANG MODEL PEMBELAJARAN LANGSUNG TERHADAP HASIL BELAJAR MATEMATIKA SISWA KELAS XI SMA NEGERI 2 BAJO
}

\author{
Oleh: ${ }^{1}$ Nuryanti $S,{ }^{2}$ Ino Sulistiani \\ ${ }^{1,2}$ Pendidikan Matematika IAIN Palopo \\ e-mail: ${ }^{2}$ inosummase@gmail.com
}

\begin{abstract}
Abstrak:
Pembelajaran langsung pada umumnya dirancang khusus untuk mengembangkan aktivitas belajar siswa yang berkaitan dengan aspek pengetahuan prosedural dan pengetahuan deklaratif yang dapat berupa fakta, konsep, prinsip, atau generalisasi yang terstruktur dengan baik dan dapat dipelajari selangkah demi selangkah. Penelitian ini merupakan penelitian expost facto yang bertujuan untuk mengetahui apakah persepsi siswa tetang pembelajaran langsung berpengaruh terhadap hasil belajar matematikanya. Lokasi penelitian ini di SMA Negeri 2 Baji Kabupaten Luwu. Sampel dalam peenitlian ini sebanyak 72 orang siswa yang tersebar kedalam 3 kelas reguler. Dari hasil penelitian diperoleh bahwa persepsi siswa tentang pembelajaran langsung berpengaruh terhadap hasil belajara matematika dengan KD 89,7\%.
\end{abstract}

Kata kunci:.Hasil Belajar Matematika, Model Pembelajaran Langsung.

\section{Pendahuluan}

Perbandingan nilai antar siswa berkemampuan baik dengan siswa berkemampuan yang kurang dapat menjadi hambatan bagi peningkatan hasil belajar siswa di sekolah. Banyak faktor penyebab dari munculnya permasalahan pembelajaran matematika di atas. Faktor tersebut meliputi faktor internal dan faktor eksternal. Faktor internal adalah faktor yang muncul dari dalam diri siswa itu sendiri, seperti tingkat intelegensi dan kepribadian. Sedangkan faktor eksternal merupakan faktor yang muncul dari luar diri siswa, seperti faktor lingkungan, model mengajar, dan sistem evaluasi. Model mengajar memiliki pengaruh besar terhadap tujuan pembelajaran. Gambaran permasalahan diatas menunjukkan bahwa pembelajaran matematika perlu diperbaiki guna meningkatkan keaktifan dan prestasi belajar siswa. Mengingat pentingnya matematika dan permasalahan matematika idealnya usaha ini dimulai dari pembenahan proses pembelajaran yang dilakukan guru, yaitu menawarkan suatu model pembelajaran yang dapat meningkatkan prestasi matematika siswa pada umumnya. 
Salah satu cara untuk mengatasinya yaitu pembelajaran dengan menggunakan model pembelajaran langsung. Model pembelajaran langsung merupakan salah satu pendekatan mengajar yang dirancang khusus untuk menunjang proses belajar siswa yang berkaitan dengan pengatahuan deklaratif dan pengatahuan prosedural yang terstruktur dengan baik yang dapat diajarkan dengan pola kegiatan yang bertahap selangkah demi selangkah. Berdasarkan hasil observasi awal, guru bidang studi matematika SMA Negeri 2 Bajo telah menerapkan sistem model pembelajaran langsung, oleh karena itu peneliti tertarik meneliti persepsi siswa tentang model pembelajaran langsung.

Berdasarkan latar belakang masalah tersebut, maka permasalahan yang ingin diselesaikan dalam penelitian ini adalah apakah persepsi siswa tetang pembelajaran langsung berpengaruh terhadap hasil belajar matematikanya. Lokasi penelitian ini di SMA Negeri 2 Baji Kabupaten Luwu

Model pembelajaran langsung adalah salah satu pendekatan mengajar yang dirancang khusus untuk menunjang proses belajar siswa yang berkaitan dengan pengatahuan deklaratif dan pengetahuan prosedural yang terstruktur dengan baik yang dapat diajarkan dengan pola kegiatan yang bertahap selangkah demi selangkah. Pengetahuan prosedural yaitu pengetahuan mengenal bagaimana orang melakukan sesuatu sedangkan pengetahuan deklaratif yaitu pengetahuan tentang sesuatu.

Pengajaran langsung tersebut berpusat pada guru, dan harus menjamin terjadinya keterlibatan siswa. Dalam hal ini, guru menyampaikan isi atau materi akademik dalam format yang terstruktur, mengarahkan kegiatan para siswa, dan menguji keterampilan siswa melalui latihan - latihan dibawah bimbingan dan arahan guru. Jadi, lingkungannya harus diciptakan yang berorientasi pada tugas - tugas yang diberikan pada siswa.

Ciri - Ciri Model Pembelajaran Langsung antara lain:

a. Adanya tujuan pembelajaran

Pembelajaran langsung ini menekankan tujuan pembelajaran yang harus berorientasi kepada siswa dan spesifik, mengandung uraian yang jelas tentang situasi penilaian (kondisi evaluasi), dan mengandung tingkat ketercapaian kinerja yang diharapkan (criteria keberhasilan).

b. Sintaks atau pola keseluruhan dan alur kegiatan pembelajaran

Pada model pembelajaran langsung terdapat lima fase yang sangat penting. Pembelajaran langsung dapat berbentuk ceramah, 
79 | al-Khwarizmi, Volume III, Edisi 2, Oktober 2015, Hal. 77 - 82

demonstrasi, pelatihan atau praktek, dan kerja kelompok. Ada lima tahapan pembelajaran langsung yaitu :

1) Tahap $1:$ menyampaikan tujuan dan mempersiapkan siswa

2) Tahap $2:$ mendemonstrasi pengetahuan dan keterampilan

3) Tahap $3:$ membimbing pelatihan

4) Tahap 4 : memeriksa pemahaman dan memberikan umpan balik

5) Tahap 5 : memberikan kesempatan untuk latihan lanjutan dan penerapan konsep

\section{Metode Penelitian}

Pendekatan yang digunakan dalam penelitian ini adalah kuantitatif. Jenis penelitian ini adalah penelitian Exppost Facto. Penelitian ini dilakukan di SMA 2 Bajo Desa Bonelemo Kecamatan Bajo Barat Kabupaten Luwu. Populasi dalam penelitian ini adalah siswa kelas XI SMA Negeri 2 Bajo yang terdiri dari 3 kelas paralel dengan jumlah siswa 72 orang. Seluruh kelas populasi diambil sebagai sampel. Desain penelitian yang digunakan dalam penelitian ini adalah sebagai berikut:

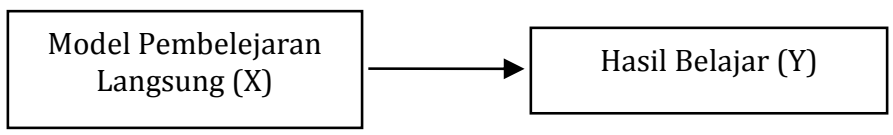

Dengan :

$\mathrm{X} \quad=$ Model pembelajaran langsung

$\mathrm{Y}=$ Hasil belajar Matematika

Data yang digunakan dalam penelitian ini ada 2 yakni data primer yang terdiri dari hasil angket persepsi siswa tentang model pembelajaran langsung, dan data sekunder berupa dokumentasi hasil belajar matematika siswa.

Sebelum diberikan kepada kelas sampel, instrumen tes terlebih dahulu divalidasi dengan menggunakan konsep validitas butir dan uji reliabilitas dengan menggunakan rumus alfa. Sleanjutnya dilakukan analisis deskriptif terhadap hasil angket dengan menghitung persentase jawaban dengan menggunakan rumus berikut:

$$
\mathrm{P}=\mathrm{F} / \mathrm{N} \times 100 \%
$$

Dengan: $\mathrm{P}=$ Persentase jawaban

$\mathrm{F}=$ Frekuensi jawaban

$\mathrm{N}=$ Banyakanya responden 
Kategori reson siswa mengacu pada kategori berikut:

\begin{tabular}{|c|c|}
\hline $\mathbf{P}$ & Kategori \\
\hline$\% \mathrm{P}=0$ & Tidak ada \\
\hline $0<\% \mathrm{P}<25$ & Sebagian kecil \\
\hline $25<\% \mathrm{P}<50$ & Hampir setengahnya \\
\hline$\% \mathrm{P}=50$ & Setengahnya \\
\hline $50<\% \mathrm{P}<75$ & Sebagian besar \\
\hline $75<\% \mathrm{P}<100$ & Hampir seluruhnya \\
\hline$\% \mathrm{P}=100$ & Seluruhnya \\
\hline
\end{tabular}

Sementara itu, analsis deskriptif hasil belajar siswa mengacu pada kategorisasi berikut:

\begin{tabular}{|c|c|c|}
\hline Tingkat Penguasaan & Skor & Kategori \\
\hline $0 \%-20 \%$ & $0-20$ & Sangat Kurang \\
\hline $21 \%-40 \%$ & $21-40$ & Kurang \\
\hline $41 \%-60 \%$ & $41-60$ & Sedang \\
\hline $61 \%-80 \%$ & $61-80$ & Tinggi \\
\hline $81 \%-100 \%$ & $81-100$ & Sangat Tinggi \\
\hline
\end{tabular}

Untuk menjawab permasalahan dalam penelitian ini, digunakan analisis korelasi dengan menggunakan rumus korelasi produc moment berikut:

$$
r_{X Y}=\frac{N \sum X Y-\left(\sum X\left(\sum Y\right)\right)}{\sqrt{\left(N \sum X^{2}-(X)^{2}\right)\left(N \sum Y^{2}-(Y)^{2}\right)}}
$$

Dengan:

$\mathrm{r}_{\mathrm{xy}}=$ Korelasi antara variabel $\mathrm{X}$ dengan variabel $\mathrm{Y}$

$\mathrm{N}=$ Jumlah siswa

$\mathrm{X}=$ Model pembelajaran langsung

$\mathrm{Y}=$ Hasil belajar matematika

Dengan interpretasi sebagai berikut:

\begin{tabular}{|c|c|}
\hline Interval Koefisien & Tingkat Hubungan \\
\hline $0,00-0,199$ & Tidak ada hubungan \\
$0,20-0,399$ & Rendah \\
$0,40-0,599$ & Cukup \\
$0,60-0,799$ & Kuat \\
$0,80-1,000$ & Sangat Kuat \\
\hline
\end{tabular}


81 | al-Khwarizmi, Volume III, Edisi 2, Oktober 2015, Hal. 77 - 82

Untuk mengetahui seberapa besar konstribusi variabel bebas (X) berpengaruh terhadap variabel terikat (Y), dihitung dengan menggunakan rumus koefisien determinasi (KD), yaitu:

$$
\mathrm{KD}=r^{2} x 100 \%
$$

Dimana:

KD: koefisien determinasi

$r^{2}$ : kuadrat dari koefisien korelasi.

\section{Hasil dan Pembahasan}

Berdasarkan uji validitas angket diperoleh bahwa semua pernyataan dalam angket dinyatakan valid dan reliabel. Selanjutnya, statistik deskriptif angket persepsi siswa tersebut disajikan dalam bentuk tabel berikut:

\begin{tabular}{|c|c|c|c|}
\hline Skor & Kategori & Frekuensi & Persentase \\
\hline $0-20$ & Sangat Rendah & 0 & $0 \%$ \\
\hline $21-40$ & Rendah & 2 & $2,8 \%$ \\
\hline $41-60$ & Sedang & 51 & $70,8 \%$ \\
\hline $61-80$ & Tinggi & 19 & $26,4 \%$ \\
\hline $81-100$ & Sangat Tinggi & 0 & $0 \%$ \\
\hline \multicolumn{2}{|r|}{ Jumlah } & $\mathbf{7 2}$ & $\mathbf{1 0 0 \%}$ \\
\hline
\end{tabular}

Sementara itu, hasil belajar matematika siswa disajikan dalam bentuk tabel berikut:

\begin{tabular}{|c|c|c|c|}
\hline Skor & Kategori & Frekuensi & Persentase \\
\hline $0-20$ & Sangat Rendah & 0 & $0 \%$ \\
\hline $21-40$ & Rendah & 0 & $0 \%$ \\
\hline $41-60$ & Sedang & 0 & $0 \%$ \\
\hline $61-80$ & Tinggi & 21 & $29,2 \%$ \\
\hline $81-100$ & Sangat Tinggi & 51 & $70,8 \%$ \\
\hline \multicolumn{2}{|l}{ Jumlah } & $\mathbf{7 2}$ & $\mathbf{1 0 0 \%}$ \\
\hline
\end{tabular}

Berdasarkan analisis korelasi diperoleh $\mathrm{r}=0,947$, dengan KD $=89,7 \%$. Artinya, pengaruh model pembelajaran langsung terhadap hasil belajar matematika kelas XI SMA Negeri 2 Bajo sebesar $89,7 \%$ sedangkan sisanya $10,3 \%$ ditentukan oleh variabel lain. Variabel lainnya yang mempengaruhi model pembelajaran langsung dapat timbul dari beberapa faktor, baik internal maupun eksternal 


\section{Kesimpulan}

Kesimpulan yang diperoleh dari penelitian ini adalah:

1. Secara deskriptif, Hasil belajar matematika siswa kelas XI SMA Negeri 2 Bajo pada mied semester tahun ajaran 2015/2016 termasuk dalam kategori yang baik dengan skor rata - rata hasil belajar matematika 83,93.

2. Model pembelajaran langsung mempunyai pengaruh terhadap hasi belajar matematika siswa kelas XI SMA Negeri 2 Bajo tahun ajaran 2015/2016 pada taraf kepercayaan 5\% dengan koefisien determinasi (KD) sebesar 89,7\% hasil belajar matematika siswa kelas XI SMA Negeri 2 Bajo dipengaruhi oleh model pembelajara langsung dan 10,3\% ditentukan oleh variabel lain.

\section{DAFTAR PUSTAKA}

Aunurrahamn, Belajar dan Pembelajaran, Bandung : Alfabeta, 2012.

Arikunto, Suharsimi, Prosedur Penelitian Suatu Pendekatan Praktik, Jakarta: PT Rineka Cipta, 2006.

Hamzah B dan Nurdin Mohammad, "Model Pembelajaran", (Cet. I ; Jakarta : Bumi Aksara, 2007)

Kartono, Kartini, Bimbingan Belajar di SMA dan Perguruan Tinggi, Jakarta : Rajawali, 1985.

M. Subana dan Sudrajat, Dasar-Dasar penelitian ilmiah, Bandung: Pustaka Setia, 2005.

Riduwan, Dasar-Dasar Statistika, (Cet. 8 ; Bandung : Alfabeta, 2010).

Rusman, Model - Model Pembelajaran, (Bandung : Ed..II ; Rajawali Pers, 2012).

Slameto, Belajar dan Faktor-Faktor yang Mempengaruhinya, Jakarta : PT Rineka Cipta, 1995.

Sugiono, Metode Penelitian Pendidikan (Pendekatan Kuantitatif, Kualitatif, dan R\&D), Bandung: Alfabeta, 2012.

Suhertien, Piet A., Konsep Dasar dan Teknik Supervisi Pendidikan, (Cet. I ; Jakarta : Rineka Cipta, 2000).

Sukardi, Metodelogi Penelitian Pendidikan, Jakarta : Bumi Aksara, 2008.

Usman, Husaini dan R. Purnomo Setiady Akbar, Pengantar Statistik, Jakarta: Bumi Askara, 1995. 